\title{
On Attaining Special Powers through Rasāyana Therapies in Sanskrit Medical Literature
}

\author{
Dagmar Wujastyk
}

In this article, I will examine the association of a particular branch of Āyurveda called rasāyana (vitalization therapy) with the development or attainment of extraordinary capabilities or special powers (siddhi). Special powers or abilities are often described in Indic literature as the necessary or incidental products of spiritual advancement: For example, a specific set of special powers (siddhi) forms an integral part of the yogic path of the Pātañjalayogaśästra. ${ }^{1}$ But what role do special powers play in medicine? Are they also part of a spiritual path, or do they have a different function in medicine? In the following, I will examine how the generation of special powers is described in Sanskrit medical literature in the context of rasāyana and will explore what this tells us about the Sanskrit medical authors' understanding of medicine. ${ }^{2}$

1 See Knut A.Jacobsen, Yoga Powers: Extraordinary Capacities Attained Through Meditation and Concentration (Leiden: Brill, 2011) on the general theme of yoga powers in Indian thought; Corrado Pensa, "On the Purification Concept in Indian Tradition, with Special Regard to Yoga," East and West 19, no. 1-2 (1969): 194-228 on the role of siddhis in Patañjali's work and in Buddhism; Philipp A. Maas, "On the Meaning of rasāyana in Classical Yoga and Āyurveda," History of Science in South Asia Special Issue "Rejuvenation, Longevity, Immortality in South Asian Medical, Alchemical and Yoga Traditions" 5, no. 2 (2017): 66-84 on the generation of yogic powers through the use of rasāyana in the Pātañjalayogaśāstra and its commentaries; and James Mallinson and Mark Singleton, Roots of Yoga (London: Penguin Random House UK, 2017), 359-394 on yogic powers in medieval yoga literature.

2 The following Sanskrit medical works were consulted for this article: the Carakasamhitā (early centuries CE), Suśrutasaṃhitā (early centuries CE), Așțāngahrdayasaṃhitā (c. seventh century), Aștāingasamgraha (c. seventh century CE), Siddhayoga (c. tenth century CE), Cakradatta (c. eleventh century CE), Vañgasenasaṃhitā, (c. eleventh/twelfth century CE), Śārngadharasamnitā (c. thirteenth/fourteenth century CE), Bhāvaprakāśa (sixteenth century CE), Yogaratnākara (eighteenth century CE), and Bhaișajyaratnāvalī (eighteenth/nineteenth century CE). Apart from the Śärrigadharasaṃhitā, all these works contain separate chapters on rasāyana. 


\section{Background}

The Indian medical tradition of Âyurveda is transmitted to us through a series of compilations, most of which are written in Sanskrit. The earliest of these, the Carakasaṃitāa and Suśrutasaṃhitā date to the early centuries of the Common Era. ${ }^{3}$ These works represent the first attempts at the systematization and codification of medical knowledge as a discipline in its own right, defining medicine as a professional occupation with a circumscribed body of knowledge. As the titles suggest, ${ }^{4}$ these works are collections, or assemblages, and as such, they unite in themselves a range of approaches to their subjects. At the same time, they are not miscellanies, but (multiply) redacted works that reflect which subjects, medical theories and practices were considered valid or at least relevant by the compilers and redactors. Later medical works build upon the early ones, ensuring continuity through an adaptive reuse of the older materials. The innovation of the later compilers and authors lies in restructuring and freshly interpreting older materials, introducing new ideas, and removing and/or replacing parts.

The early Sanskrit medical works propose a division of medical knowledge into eight subject areas, each representing medical specializations. In the Carakasamhitā (Sūtrasthāna 30.28), these are listed as: 1. general medicine (kāyacikitsā); 2. the surgical treatment of body parts above the shoulders (śalākya); 3. the removal of foreign bodies, surgery (śalyāpahartrka); 4. toxicology (vișagaravairodhikapraśamana); 5 . the treatment of possession by supernatural beings (bhütavidyā); 6. pediatrics (komārabhrtyaka); 7. vitalization therapy (rasāyana); and 8. aphrodisiacs and treatments relating to virility (väjikkarana). The Suśrutasaṃhitā records a similar list, albeit in a different order. ${ }^{5}$ While

3 Both works have complicated transmission histories with several historical layers. For a survey of the proposed dates of the different redactions of the Suśrutasamhitā, see Jan Gerrit Meulenbeld, A History of Indian Medical Literature (Groningen: Egbert Forsten, 1999-2002), IA, $342-352$. The Carakasam hitā is presented as a revised version of an ancient work on medicine (the Agniveśatantra), the date of which is uncertain. The version of the Carakasamhita that has been transmitted to us is a redacted version that was edited and added to by a scholar called Dṛ̂habala in about the fifth century. See Meulenbeld, A History of Indian Medical Literature, IA: $105^{-115}$ for a detailed discussion of the issues surrounding the dating of the Carakasamnitā. Also see the article by Philipp A. Maas, "On What Became of the Carakasaṃhitā After Dṛ̣habala's Revision," eJournal of Indian Medicine 3, no. 1 (2010): 1-22. "Saṃhitā" means "collection."

5 See Suśrutasaṃhitā Sūtrasthāna 1.7. The list reads: 1. surgery (śalya); 2. surgery above the shoulders (śalākya); 3. general medicine (kāyacikitsāa); 4. treatment of posession (bhūtavidyā); 5. pediatrics (kaumārabhrtya); 6. toxicology (agadatantra); 7. vitalization therapy (rasāyana); and 8. virility therapy (vājikkaranatantra). 
both these works note that a physician should have proficiency in all areas of medicine, their descriptions of the different medical subjects display marked differences in methodological approaches, which may reflect older divisions among medical practitioners into groups with distinct specializations. For example, while general medicine was predicated on humoral theory and associated physiological processes, these initially played no role in the context of toxicology, or vitalization and virility medicine. ${ }^{6}$

\section{$2 \quad$ What Is Rasāyana?}

The branch of Āyurveda called rasāyana, which I have rendered as "vitalization therapy" above, is dedicated to the prolongation of life, rejuvenation, antiageing and the preservation or promotion of health and well-being. ${ }^{7}$ The term rasāyana also denotes the therapies that together constitute this branch of medicine and the medical substances and formulations used in these therapies. Many Sanskrit medical works dedicate whole sections to the topic of rasāyana. Often, these sections are juxtaposed or, especially in later works, merged with sections on virility therapy (vrșya/vājīkarana $).{ }^{8}$ Rasāyana formulations and references to substances that function as rasāyanas are also found interspersed throughout Sanskrit medical works.

The medical treatises offer some definitions of rasāyana, or rather, of what is meant to be achieved through rasāyana. For example, the Carakasamhitā

6 This changed: For example, humoral theory was integrated into vitalization therapy ( $r a s \bar{a}-$ yana) from the c. seventh-century medical work Aștāingahrdayasamnitā onward. I would like to thank Prof. Francis Zimmermann for this important observation, made at the Ayuryog workshop in October 2017 (http://ayuryog.org/event/ayuryog-workshop-rejuvenation-longev ity-immortality-perspectives-rasāyana-kāyakalpa-and-bcud). However, the humors were still only of marginal importance in the Aștāingahṛdayasamnhitā's description of vitalization therapy and remained a fairly minor element in vitalization therapy in general. The exception to this rule is the eleventh-/twelfth-century Vargasenasamhitā, which describes an array of tonics specifically formulated for treating disorders of the humors.

7 The term rasayyana is somewhat elusive, due to the polyvalent meanings of its elements, in particular of rasa. See Dagmar Wujastyk, "Acts of Improvement." History of Science in South Asia Special Issue "Rejuvenation, Longevity, Immortality in South Asian Medical, Alchemical and Yoga Traditions" 5, no. 2 (2017): 1-2 and especially Maas, "On the Meaning of rasāyana," 7579 , which discusses the term at length and concludes that the different interpretations of the term by the Sanskrit medical authors show a certain level of uncertainty concerning its meaning. I therefore leave it untranslated in this article, unless it is clearly used in the sense of "tonic."

8 See Kenneth G. Zysk, "Potency Therapy in Classical Indian Medicine," Asian Medicine 1, no. 1 (2005): 101-118 on potency (= virility) therapy in classical Indian medicine. 
defines rasāyana as therapies that promote strength and vigor in the healthy. ${ }^{9}$ Its more detailed definition reads as follows:

Through rasāyana, a man gains longevity, memory, mental power, health, youthful vigor, a great radiance, complexion, and voice, an extremely strong body and keen senses, mastery of speech, respect, and beauty. ${ }^{10}$

One of the Carakasaminhitä's listed effects, "mastery of speech" (vāksiddhi), points to the aspect of rasayyana we will examine further here, namely the attainment of special powers. As explained elsewhere, "mastery of speech" could be understood to refer to excellent oratorical skills, or even just to a strong or pleasant voice. ${ }^{11}$ Regaining or attaining a strong voice is certainly documented as one of the functions of rasāyana: a number of formulations are indicated for strengthening the voice and combating hoarseness (svarabheda)..$^{12}$ However, the function of curing hoarseness seems already covered by "svaraudāryam"- "greatness of voice." The attainment of "mastery of speech" in the sense of oratorical skills or eloquence is perhaps less easily explained in terms of overcoming a pathology, unless mastering speech is understood to mean counteracting stammering or other problems with coordinating speech..$^{13}$ Since the term $v \bar{a} k s i d d h i$ to my knowledge only occurs twice in the Carakasamnitā (both times without explanation), it is impossible to know what

9 See Carakasaṃhitā Cikitsāsthāna 1.1. 1-8. In the edition of the Carakasaṃhitā used here, the rasāyana chapter is located in the section on therapeutics (Cikitsāsthāna) and it is divided into four subchapters ( $p \bar{a} d a)$ : 1. abhayāmalakīyo rasāyanapāda ("the rasāyana section dedicated to the chebulic and emblic myrobalans"); 2. prānakāmīyo rasāyanapāda ("the rasāyana section dedicated to the desire for vital breath"); 3. karapracitīyo rasāyanapāda ("the rasāyana section dedicated to hand-plucked (emblic myrobalan fruits)"); and 4. àyurvedasamutthānāyo rasāyanapāda ("the rasāyana section dedicated to the uplift of the science of life").

10 Carakasaṃhitā Cikitsāsthāna 1.1.7-8ab: dìrgham āyuḥ smṛtị̣ medhām ārogyam taruṇam vayạ̣ / prabhāvarṇasvaraudāryam dehendriyabalạ̣ param //7// vāksiddhiṃ praṇatịn kāntim labhate nā rasāyanāt / This passage recurs in a number of later medical texts, albeit with some variations. See Wujastyk, "Acts of Improvement," 5-7.

11 Dagmar Wujastyk, "On Perfecting the Body: rasāyana in Sanskrit Medical Literature," AION-sezione filologico-letteraria 37 (2015): 57. Maas, "On the Meaning of rasāyana," 74.

12 On hoarseness, see, for example, Carakasaṃhitā Cikitsāsthāna 1.1.71, 1.2.3, 1.3.27. The strengthening of the voice is often mentioned in conjunction with the increase of strength (bala), digestion (agni) and complexion (varna).

13 Stammering is typically associated with a dysfunction of the humor wind and is not explicitly addressed in rasāyana chapters. On stammering as a wind- ( $v \bar{a} t a)$ induced disease, see, for example, Suśrutasaṃhitā Cikitsāsthāna 1.85. 
exactly was meant. However, in the eleventh century, the commentator Cakrapānidatta explained $v \bar{a} k s i d d h i$ as a special power through which "whatever is said, inevitably arises."14 According to this interpretation, someone in possession of $v \bar{a} k s i d d h i$ would automatically speak the truth since any statement they made would consequently become true. In other words, not only would they speak the truth, they would produce truth, creating reality through the act of speaking. ${ }^{15}$

The idea that humans can gain access to special powers, usually through spiritual practices, is found in many sources in Indian literature and is also discussed in early medical literature. While rasāyana chapters in medical works describe the attainment of special powers through the intake of medicine, the Carakasamnitā also gives a short list of special powers attained through yogic practice in Śārīrasthāna 1.140-141:

Entering someone's mind, knowledge of objects, free action, vision, hearing, recollection, beauty, and invisibility at will: these are called the eightfold lordly powers that yogins have. All that arises from meditation with a purified mind. ${ }^{16}$

Notably, vāksiddhi is not among this list, although one could perhaps make an argument that "free action" may describe a similar phenomenon. Vision, hearing, recollection, and beauty are central aims of rasāyana treatments, while invisibility does not feature as an effect of rasāyana. Thus, while there is some overlap, the extraordinary capabilities described in its rasāyana chapter do not fully correspond to the group of eight powers attained through yogic practice outlined in the Carakasamnhitā's Śārirasthāna.

A complex picture of the variety of goals pursued with rasāyana treatment emerges when we look at the various rasāyana sections of the medical and alchemical works and examine what effects are attributed to their formula-

14 vāksiddhih yad ucyate tad avaśyam bhavatīty arthah —Cakrapāṇidatta on Carakasaṃhitā Cikitsāsthāna 1.1.7-8.

15 See the discussion of this passage in Maas, "On the Meaning of rasāyana," 72-75. Also see Lloyd W. Pflueger, "Holding On and Letting Go: The In and Out of Power in Classical Yoga," in Yoga Powers: Extraordinary Capacities Attained Through Meditation and Concentration, ed. Knut Jacobsen (Leiden: Brill, 2011), 251 on the concept of the conformation of one's words with reality.

16 Dominik Wujastyk, "The Path to Liberation through Yogic Mindfulness in Early Ayurveda," in Yoga in Practice, ed. David Gordon White (Princeton: Princeton University Press, 2011), 40. This list of eight differs from the more common list of eight special powers of the Pātañjalayogaśāstra. 
tions. The described effects of rasāyana medicines and procedures can be broadly divided into five, partly overlapping, thematic groups: ${ }^{17}$

1. Health: Medicines and procedures used for the prevention or cure of disease, and for the establishment of overall well-being, including the proper functioning of the body and senses.

2. Ageing: Medicines and procedures attributed with effecting rejuvenation, anti-ageing, or the increase of lifespan.

3. Cognitive power: Medicines and procedures that restore, establish or enhance memory power, memorization ability and intelligence.

4. Virility: Medicines and procedures which restore or enhance sexual stamina, bodily strength and fertility.

5. Special powers/extraordinary capacities/perfections (discussed below).

Rasāyana formulations most often unite a range of benefits from several, and in some cases all, thematic groups. However, there are many examples of rasāyana tonics that have a specific focus or a bias toward one group, such as the "medhyarasāyana," medicines for the improvement of cognitive faculties. It is also not always possible to neatly discern one group from the other. Health and ageing could both be considered the overarching category, since the occurrence of certain diseases, or the loss of cognitive or sensory powers or problems concerning sexual stamina may be understood in terms of health problems, but also in terms of ageing, i.e., health problems caused or exacerbated by the ageing process. These are also the dominant terms in the definitions of rasāyana in later medical literature, ambiguously presented in a compound ( jarāryādhi) that allows to understand them as the separate categories of "ageing and diseases," or as a combined category of "diseases caused by ageing."18

However, the group of special powers does not in all cases fit either category of health or ageing. I would like to suggest a division into two kinds of special powers. The first kind consists of powers unconnected to a medical framework of a patient's bodily and mental health and well-being, or the absence or pres-

17 See Dagmar Wujastyk, "Acts of Improvement" for a more detailed discussion of the applications of rasāyana. Also see Oliver Hellwig, "Rasāyana und die āyurvedische Krankheitskunde," Traditional South Asian Medicine 8 (2008): 32-64, which discusses the aims of rasāyana of treating "self-arisen" (svabhāva) diseases in the Suśrutasaṃhitā.

18 See Siddhayoga 69 (rasāyanādhikāra): yaj jarāryādhividhvamssi bheșajam tad rasāyanam / ("a rasāyana is a remedy that removes ageing and disease (or: that removes diseases [caused by] ageing)"). The same phrase appears in Cakradatta 66 (rasāyanādhikāra) 1; Vañgasenasaṃhitā rasāyanādhikāra 371; and BhaișajyaratnāvalīUttarakhaṇda 73 (rasāyanaprakaraṇam), 1. Śārngadharasaṃhitā 1.4.13 gives a similar definition: rasāyanam ca taj jñeyam yaj jarāryādhināśanam // ("rasāyana is known as that which removes disease caused by ageing"). 
ence of disease. ${ }^{19}$ Rather, their function seems to be to manipulate the world in favor of the person using the rasāyana, in particular influencing the person's social standing and general fortune and therefore affecting not only the consumer, but also other persons or the environment. Rasāyana preparations associated with these kinds of powers address human vulnerability to malign forces (both human and non-human) and the evil intent of others.

The second kind of special powers does not so much stand outside a medical framework of health and well-being, but rather extends it by redefining what is possible in terms of perfecting the body and its functions. This kind of rasāyana addresses a wider spectrum of human corporeality and functioning.

\section{$3 \quad$ Good Luck and Protection from Malign Forces}

A number of rasāyana medicines are attributed with affording the consumer fame, success, wealth, charm, valor, good fortune, eloquence, or success in debates; securing the favor of the king or other powerful persons; subduing the will of others; preventing misfortune; protecting from the evil intentions and actions of others (in particular from witchcraft and damaging mantras), or from possession by evil spirits or bad dreams; and removing wrongdoing (pāpman, $p \bar{a} p a$ ). We meet with these kinds of effects throughout the examined rasāyana chapters, though the frequency of their occurrence differs from work to work.

The Suśrutasaṃhitā's presentation of rasāyana in Cikitsāsthāna 28 provides a number of recipes that are specially dedicated to this kind of effect:

Gold, lotus seeds, honey, parched grain and beautyberry (priyaingu), taken with cow's milk, should ward off bad luck. ${ }^{20}$

A decoction of the petals of the blue lotus boiled with cow's milk together with gold and with sesame is thought to destroy bad luck. ${ }^{21}$

19 The objective of Āyurveda is defined as freeing the diseased of disorders and protecting the health of the healthy in Suśrutasaṃhitā Sūtrasthāna 1.14. This is echoed in the beginning of the Carakasamnhitā's rasāyana chapter (Cikitsāsthāna 1.1.4), which states that healing (bheșaja) is twofold, dividing it into what promotes strength in the healthy, and what eradicates disorders in the diseased.

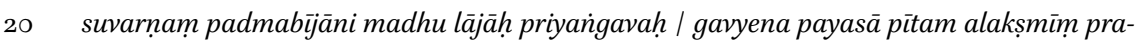
tiședhayet // 14

21 nülotpaladalakvātho gavyena payasā śrtaḥ / sasuvarṇas tilaịh sārdham alakṣmināśanạ̣ smrtah // 15 
Wild asparagus (śat $\bar{a} v a r \bar{\imath})$ butter used properly every day together with honey and gold will place the king under one's power. ${ }^{22}$

A compound of sandalwood, mohanikā, licorice, pyrites, honey and gold should be taken by one who desires good fortune. ${ }^{23}$

This kind of special effect is somewhat less developed in the Carakasamnitā. We find examples in two recipes:

A man who takes an iron tonic for a year will become
intelligent, famous, a master of speech,
one who retains what he has heard, and very wealthy. ${ }^{24}$

This powerful aindra (waterhyssop?) tonic is extremely energizing and neither enchantments, nor bad luck, poison or disease can withstand it. 25

Similarly, such effects also play only a minor role in the Aștāngahrdaysaṃhitā, where they occur in only two (out of about sixty-seven) recipes in the rasāyana chapter. The first, a multiple-herb ghee called brāhmyādighrta found in Uttarasthāna 39.50-53 promises the user a multitude of benefits, among them prosperity and a bright and beautiful appearance, as well as the cure of problems caused by spells. The latter are specified as "atharvamantra," i.e., spells

22 śatāvarīghrtam samyagupayuktạ̣ dine dine / sakșaudram sasuvarṇaṃ ca narendram sthāpayed vaśe // 21

23 gocandanā mohanikā madhukaṃ mākșikaṃ madhu / suvarṇam iti saṃyogaḥ peyah saubhägyam icchatā // 22

I was not able to identify the plant "mohanikā" and the occurrence of this name in the Suśrutasam hitā was the only one I was able to find. The name translates as "the confusing".

24 dhīmān yaśasvī vāksiddhị śrutadhārī mahādhanaḥ / bhavet samāṃ prayuñjāno naro lauharasāyanam // Carakasaṃhitā Cikitsāsthāna 1.3.22. The full recipe is found in verses $15^{-23}$.

25 paramojaskaraṃ caitat siddham aindram rasāyanam / nainat prasahate krtyā nālakșmīr na vișaṃ na ruk // Carakasaṃhitā Cikitsāsthāna 1.3.28. The full recipe is found in verses 2429. Regarding ojaskara, "bestowing ojas," as "energizing": Ojas is a concept connected to the digestive process in Āyurvedic literature. It is the end product of the transformation process of one bodily element (dhātu) into the next. It is sometimes interpreted as something akin to life force, hence my rendering as "energizing". On the varying meanings of ojas in different Indic literatures over time, see Jan Gerrit Meulenbeld, "The Woes of ojas in the Modern World," in Modern and Global Ayurveda: Pluralism and Paradigms, eds. Dagmar Wujastyk and Frederick M. Smith (Albany: SUNY Press, 2008), 157-175. 
associated with the Atharvaveda, the fourth of the Vedic liturgical scriptures. Presumably, this is a reference to mantras categorized in the Atharvaveda as "añgirāmantra" or "āngiras," i.e., mantras for harming others (abhicāra). ${ }^{26}$ The second recipe is found in Aștāngigahrdaysaṃhitā Uttarasthāna 39.169-173. It details the preparation of a medicated ghee called "nārasiṃha" ("associated with Narasimha," i.e., the man-lion incarnation of the god Viṣnu), and lists becoming wealthy (śrimat) and devoid of wrongdoing (nirdhütapāpman) among the medicine's many effects.

The Aștāngasamgraha's rasāyana chapter, which presents about 183 recipes, is much longer than the Aștāngahrdayasamnhitā's. Correspondingly, it contains more recipes for the attainment of special powers, though the majority of its recipes are focused on eradicating disease, supporting cognitive power and procuring longevity. The chapter includes variations of a number of the recipes from the Suśrutasaṃhitā presented above: A recipe of gold, lotus seeds, honey, grains and beautyberry against bad luck,27 a compound of gold, wood-apple, sweet flag, and clarified butter for prosperity (and beauty, health, longevity, and nourishment); ${ }^{28}$ a preparation of wild asparagus and clarified butter with gold and honey to subjugate the king. ${ }^{29}$ The Asțāngasamgraha also reiterates recipes associated with special powers from the Aștāngahrịayasamnitā: the recipe for brāhmyādighrta ${ }^{30}$ and the one for närasimhaghrta. ${ }^{31}$ It further

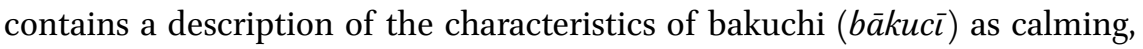
bestowing wealth, and dispelling poisons, evil spirits, misfortune, and wrongdoing. ${ }^{32}$ A recipe for sweet flag ghee promises success in all activities; ${ }^{33}$ one for elephant creeper root ghee protection from sickness, possession by spirits, wrongdoing, and bad luck. ${ }^{34}$ A recipe for śiva auțikā ("auspicious pill") is described in much detail. Based on rock resin or bitumen (śiläjatu), this pill is presented as an effective wide spectrum medicine (forty-seven disease groups

26 On this classification of mantras for harming others in the Atharvaveda and its ancillary texts, see Teun Goudriaan, Māyā Divine and Human (Delhi, Varanasi, Patna: Motilal Banarsidass, 1978): 221.

27 Aștāngasamgraha Uttarasthāna 49.57.

28 Aștāingasaṃgraha Uttarasthāna 49.6o.

29 Aștāñgasaṃraha Uttarasthāna 49.61.

30 Așțāngasaṃgraha Uttarasthāna 49.69-72 and Aștāngahṛdayasaṃhitā Uttarasthāna 39.50-53.

31 Aș̣̂āingasaṃgraha Uttarasthāna 49.394-398 and Aștāñgahrdayasaṃhitā Uttarasthāna 39.169-173.

32 Așțāngasaṃgraha Uttarasthāna 49.155 a: iti śamanì dhanyeyam vișagarabhūtopasargapāpmaghnī 1

33 Așțāngasaṃgraha Uttarasthāna 49.159: sarvārtheșu siddhimān (...) bhavati.

34 Aș̣āñgasaṃgraha Uttarasthāna 49.343-346. 
are listed), and an antidote to all sorts of poisons (animal, herbal, and mineral). It is also attributed with protecting the consumer from malevolent spells, bad dreams, evil spirits, evil, and misfortune, as well as with bestowing wealth, beauty, fame, and good fortune. Finally, it is also meant to procure the favor of the king; and to make a person win debates. ${ }^{35}$ This formula remained popular in the following centuries: it reappears a number of times in later works in rasāyana chapters. ${ }^{36}$

The Bower Manuscript's rasāyana chapter mostly describes formulations with medicinal functions, i.e., for general health and against specific disease groups. However, its version of the widely adopted "increasing long pepper" (pippalīvardhamāna) recipe is ascribed with effecting good fortune (lakșmī), a growth of luck (śrī) and general success (siddhi). ${ }^{37}$

The Siddhayoga's rasāyana chapter contains only one recipe for a medicine with extra-medical special effects, namely a rasāyana based on puncture vine (gokșura) that is supposed to make the consumer powerful and fortunate (as well as beautiful, long-lived, and sexually active). ${ }^{38}$ In the Cakradatta, extramedical special effects are noticeably absent, the one exception being the inclusion of a recipe for śiva a guțikā (spelled "gudikä" in this version), which lists the same effects as the older version from the Aștāingasamgraha. ${ }^{39}$

The Vangasenasaṃhitä's rasāyana chapter is structured very differently than those of all the other works examined here. It includes materials that seem to be interpolations rather than integral parts of the subject of rasāyana. For example, the chapter begins with recipes for various kinds of vinegars and medicated fats not found in any other rasāyana chapter. It also contains a discussion of marmans, i.e., vital points in the body, ${ }^{40}$ a description of a method of treatment with a head-pouch (sirovasti $)^{41}$ and lists of diseases associated with particular humoral substances. ${ }^{42}$ The other parts have a strong focus on the medical effects of its rasāyana formulations: about half of its recipes are for medicines aimed at specific disease groups. Otherwise, the focus is on longevity and

35 Aștāingasamgraha Uttarasthāna 49.309-325.

36 Recipes for śivā guțikā are found in Cakradatta 66. 172-193, Vargasenasaṃhitā rasāyanādhikāra 14-30, and Bhaișajyaratnāvalì Uttarakhaṇda 73.151-175.

37 See Bower Manuscript 2.6.4 and 22.

38 Siddhayoga $69.48-49$.

39 See Cakradatta 66. 172-193.

40 Vañgasenasaṃhitā rasāyanādhikāra $33^{2-350 .}$

41 Vañgasenasaṃhitā rasāyanādhikāra 331.

42 Vañgasenasaṃhitā rasāyanādhikära $35^{1-360}$ diseases associated with the humor wind (vāta), $361-365$ diseases associated with the humor bile (pitta), $366-369$ diseases associated with the humor phlegm (kapha). 
rejuvenation and the enhancement of cognitive powers. Nevertheless, some recipes do list special "good luck" powers among their effects. The Vangasenasaṃhitā includes the recipe for śivā guțikā, again with the same expected effects of protecting the consumer from malevolent spells, bad dreams, evil spirits, evil, and misfortune; as well as with bestowing wealth, beauty, fame, and good fortune. ${ }^{43}$ Its flagship recipe, a formulation based on mica (abhraka), ${ }^{44}$ offers a multitude of benefits, including becoming brave (śüra) and a good orator (vāgmin), and enjoying the fruits of the aims of human life (trivargaphalabhäjana), ${ }^{45}$ i.e., experiencing success in all spheres of life.

Neither the Bhāvaprakāśa, nor the Yogaratnākara include such special effects in their descriptions of the effects of rasāyana. Finally, the Bhaișajyaratnāvali reintroduces the theme by including a recipe for śivā gudikā (151-175) with the same effects as described in the older works. It also describes a recipe for a pill called śrisiddha (44-53), which it attributes with letting the consumer attain the eight special powers (siddhi). ${ }^{46}$ These are presumably the classic eight yoga powers detailed in the Pātañjalayogaśāstra, though the author may have also had alternative lists of siddhis in mind, such as those described in the Carakasaṃhitā.

The other kind of special effects of rasāyana medicines and therapies aim at extending human capacities and attaining a god-like perfection of the body, mind, and senses. This includes the attainment of extreme longevity, superhuman strength and beauty, complete immunity of the body, and extraordinary eyesight.

A passage from the Suśrutasam hitā, which describes the use of Soma, ${ }^{47}$ may serve as an example of these kinds of special effects of rasāyana medicines:

43 Vañgasenasaṃhitā rasāyanādhikāra 15-30.

44 Vañgasenasaṃhitā rasāyanādhikāra 136-166.

45 The three aims in human life (trivarga) are artha, käma and dharma, i.e., wealth; physical pleasure and love; and virtue.

46 See Bhaișajyaratnāvalì Uttarakhanda $73 \cdot 15^{-175}$, and 44-53, respectively.

47 Soma is frequently mentioned in the Rgveda (one of the ancient Indian liturgical texts), with many hymns praising its energizing qualities. It is not clear, however, in what relation the Soma of the medical works stands to that of Vedic literature. On the identification of the Soma plant, see Harry Falk, "Soma I and II," Bulletin of the School of Oriental and African Studies $5^{2}$ (1989): 77-9o. On Soma in the Suśrutasaṃhitā's rasāyana chapter, see Dagmar Wujastyk, "On Perfecting the Body," 62-63. 
The visionary man who makes use of the king of plants, Soma, wears a new body for ten thousand years. Neither fire, nor water, neither poison, blade nor projectile are powerful enough to take his life. He gains the strength of a thousand well-bred, sixty-year-old, rutting elephants. If he wants to go to the lands of northern legend, to the milky ocean, or even to the abode of the king of the gods, nothing can stand in his way. He is as beautiful as the god of love, as attractive as the second moon. He is radiant and brings joy to the hearts of all creatures. He truly knows all sacred knowledge, with all its branches and sub-branches. He moves like a god through the whole world, with infallible power. ${ }^{48}$

This potion promises all: extreme longevity; immunity, indeed indestructibility, of the body; superhuman strength (including virile power) and beauty; a transcendence of bodily constraints in the ability to go wherever one wishes; and a complete grasp of all sacred knowledge. In other words, the intake of Soma lets its consumer attain a god-like state.

Compare this with the more moderate effects of another rasāyana recipe from the Suśrutasamnitā:

One whose impurities have been removed should enter the hut, ${ }^{49}$ and should consume a lump of sweetflag about the size of an emblic myrobalan after it has been sanctified by oblations together with milk. Once this has been digested, milk, clarified butter, and boiled rice serve as food. Having done this for twelve days, his hearing becomes unimpeded, after using it for twice the amount of time, he becomes someone who has good memory, after using it for thrice the amount of time, it lets him retain what he hears, using it for four times twelve days, he transcends all sins, attains eagle ${ }^{50}$ vision and a lifespan of one hundred years. ${ }^{51}$

Barring the transcendence of all sins and perhaps the attainment of eagle vision (unless this simply means very good vision and not literally vision like that of the divine Garuda), the effects of this rasāyana substance fall well

48 Translation of Suśrutasaṃhitā Cikitsāsthāna 29, 14-19 by Dominik Wujastyk, The Roots of Ayurveda (London: Penguin Books, 2003), 130.

49 On the use of special buildings as part of rasāyana therapy, see Arion Roşu, "Considerations sur une technique du rasāyana āyurvedique," Indo-lranian Journal 17 (1975):1-29 and 395 and Dagmar Wujastyk, "On Perfecting the Body."

50 Tärksya is a synonym of the legendary bird Garuḍa, the mount of the god Viṣnu, who was attributed with extremely good vision.

$5^{1} \quad$ Suśrutasaṃhitā Cikitsāsthāna 28.7. 
within the range of ordinary expectations of medicine, i.e., a general improvement of the senses (in this case hearing and eyesight) and cognitive power (memory and memorization ability) and a good life expectation.

I would like to suggest that these two recipes and their effects describe different points on a spectrum of the human condition that spans a range of conditions: Bad health, deficient cognitive and sensory function, and early death on the one end; good health, satisfactory cognitive and sensory function, and normal life expectancy in the middle; perfect health, outstanding cognitive and sensory powers, and extreme longevity or even immortality on the far end of the spectrum. ${ }^{52}$ The second recipe is mostly aimed at achieving the middle conditions, the first the conditions at the far end of the spectrum.

The perfection of the body to a god-like state and the extreme extension of lifespan are central themes for these kinds of special powers at the far end of the spectrum.

Bodily Perfection: When the Body Becomes like a Stone

Many rasāyanas are described as effecting either a return to youthfulness or a halting of the ageing process. Youthfulness is associated with bodily strength, proper functioning of the senses (especially eyesight), and beauty. The more superlative descriptions promise a bodily perfection in which the body is beautiful and strong, but also immune to deterioration and impervious to damage.

The stability of the body, described with terms such as sthira ("firm") or drdha ("hard"), or by likening the body to hard materials, is frequently mentioned. For example, Carakasaṃhitā Cikitsāsthāna 1.1.77 asserts that the body will become firm as a stone ( $g$ àtram aśmavat sthirībhavati), while later medical and also alchemical literature refers to a "diamond body" or "adamantine body" (vajrakāya). ${ }^{53}$ This is a concept well-known from Mahāyāna scriptures, where it is associated with the extreme longevity or even absolute permanence, freedom from sickness, and purity of a Buddha's body. ${ }^{54}$ In medical and alchemical

$5^{2}$ I would like to thank Dominik Wujastyk for suggesting the idea of a spectrum of the human condition to me.

53 For example, in Vañgasenasaṃhitā rasāyanādhikāra 100 (full recipe: 93-100). For instances of the term in Sanskrit alchemical literature, see Rasaratnākara Rasendrakhanda 4. 19 and 86 and Rasaratnākara Rasāyanakhaṇ̣̂a 2.11, 2.42, 3.214, 4.14 and 4.47, and in Rasārnava 18.185 .

54 On the changing concepts of the vajrakāya in Buddhist literature, see Michael Radich, "Immortal Buddhas and Their Indestructible Embodiments," Journal of the International Association of Buddhist Studies 34. no. 1-2 (2011(2012)): 227-290. 
literature, it is used for its imagery of hardness, the idea of both impenetrability and unbreakableness. We encounter this idea early on, as seen in the example of the Suśrutasamhitä's description of the effects of Soma, namely that neither fire, nor water, poison, or any weapons can damage the transformed body; and in an iron preparation in the Aștāingasamgraha that lets the consumer "overcome all troubles and become unassailable by disease, ageing, death, weapons, fire, water, and poison." ${ }^{55}$

The idea of perfecting the body is, however, also connected with that of rebuilding the body. And this necessitates its prior disintegration. The fullest expression of this process is again found in the Suśrutasamnhitä's description of rasāyana therapy with Soma: a long process, in which the body progressively disintegrates, shedding impurities and old layers, to then begin its renewal and gradual transformation into god-like perfection. ${ }^{56}$ The Carakasamhitä describes comparable effects for a treatment which involves sealing the patient's body in a covered wooden barrel post-rasāyana-intake. The body would gradually dissolve and then regenerate after six months, having become similar to the gods in appearance, knowledge and powers. ${ }^{57}$

The theme of disintegration and regeneration is also present in another context, namely in the rasāyana treatment of kuștha, i.e., a group of skin diseases and particularly a disease with the symptoms of what now might be diagnosed as leprosy. ${ }^{58}$ As mentioned, many rasāyana formulations are described as cures to various diseases, especially serious ones considered particularly difficult or even impossible to treat. Kustha is one of them, and indeed probably the most widely mentioned disease in rasāyana chapters. Its symptoms, the falling off of skin and extremities, parallel the body's disintegration described in the Suśrutasamnhitā's and Carakasamnhitā's extreme rasāyana therapies. The medical texts promise a complete cure of kuștha through rasāyana, but more than that, they describe a reconstitution of the body reminiscent of the regeneration of

55 Aștāngasamgraha Uttarasthāna 49.53.

56 See Suśrutasaṃhita Cikitsāsthāna 29.10-12. See also the translation of the passage in Dominik Wujastyk, Roots, 126-129 and a discussion of it in Roşu, "Considerations," 13-15.

57 See Carakasamhitā Cikitsāsthāna 1.4.7. The theme of shedding layers of the body for a nonageing and long-lived body is also found in Sanskrit alchemical literature, as for example in Rasaratnākara rasāyanakhaṇda 4.59, which reads: jīved brahmadinam yāvat sarpavat kañcukam tjayet // ("He would live a day of Brahma while shedding his layers like a snake"). Kusț ca can describe a group of diseases characterized by symptoms primarily showing on the skin. Here, the symptoms described seem to point to leprosy more specifically. However, in modern medical terms, leprosy is a long-term infection by particular bacteria. Āyurvedic works do not have a concept of infection by bacteria and offer a different model of how the different kinds of kuștha develop. 
the disintegrated body after Soma or barrel therapy, with the nose, ears, fingers and indeed any limbs that have fallen off growing back again. ${ }^{59}$ The cure of kuștha is already a bold claim; the rasāyana's effect of giving someone the power to regenerate the body, however, is extraordinary. It confirms the image of rasāyana medicines and therapy as effective in otherwise hopeless cases, a cure that can cheat death and overcome the ravages of time and disease.

Suśrutasaṃhitā Sūtrasthāna 35.7-11 describes a lifespan of seventy years as a medium life expectation and twenty-five years as a short lifespan. ${ }^{60} \mathrm{~A}$ long life would necessarily go beyond a medium life expectation of seventy years, though we are not told by how much. The promise of reaching one hundred years in a healthy condition occurs frequently in rasāyana chapters and can perhaps be understood as a natural, or normal limit. However, some formulations are credited with providing even longer spans of life. In the Suśrutasaṃhitā's rasāyana chapter, we find recipes that are described as prolonging life up to $300,500,800,2000$, and 10000 years. Such claims are found throughout the examined medical works. However, in the Carakasamhitä's narrative, such extended lifespans are usually associated with a deep past and a particular demographic, namely Vedic sages. These are presented as the original recipients of Âyurvedic knowledge and the first consumers of rasāyana medicines. ${ }^{61}$ Rather than stating that a particular rasāyana will let someone live for several centuries, the treatise narrates how a formulation affected sages in the past: Sage Cyavana became young and virile again, the Vaikhānasa and Bālakhilya sages attained an unlimited lifespan. ${ }^{62}$ As prototypical consumers of rasāyanas, the sages also set the standard for future recipients of rasāyana

59 See, for example, Aștāingahṛdayasaṃhitā 39.109-110, which describes the application of a somarājī seed medicine for growing new limbs in the case of kuștha.

6o See Christèle Barois, "Stretching Out Life, Maintaining the Body: Part I-Vayas in Medical Literature," History of Science in South Asia Special Issue "Rejuvenation, Longevity, Immortality in South Asian Medical, Alchemical and Yoga Traditions" 5, no. 2 (2017): 37-65 on different presentations of normal lifespan in Sanskrit medical literature.

61 For example, see Carakasaṃhitā Cikitsāsthāna 1.1.75, which states that the sages lived for countless hundreds of years (anekavarșaśatajīvano) after taking rasāyana medicines, or Cikitsāsthāna 1.1.54 and Cikitsāsthāna 1.2.21 which relates that sages attained an unlimited lifespan (amitāyus) through rasāyana.

62 See the recipe for cyavanaprāśa in Carakasaṃhitā Cikitsāsthāna 1.1.62-74 and for brahmarasāyana in Cikitsāsthāna 1.1. 41-57. 
therapy, who, according to Carakasaṃhitā Cikitsāsthāna 1.4.30-35, need to be self-restrained, of impeccable moral conduct, and intent on spiritual practices. Those who do not fulfil these requirements would not be able to benefit from treatment. This general idea also appears in the Suśrutasaṃhitā (Cikitsāsthāna $28.32,30.4$ and 30.28-29), where the crucial ingredients of Soma or a divine herb can only be found and used by worthy persons. Nevertheless, the treatises do allow for the possibility that anyone following certain behaviors can reap the same benefits of rasayyana treatment the sages purportedly enjoyed. The Carakasaṃhitā (Cikitsāsthāna 1.1.78-8o) states:

The application of rasāyana was to the great sages of old as nectar was to the gods and ambrosia to the serpent-deities.

In old times, those occupied with rasāyana experienced neither ageing nor weakness, illness or death for thousands of years.

One who undertakes rasāyana according to rule does not merely attain a long lifespan in this world. He follows the auspicious path pursued by the divine sages and attains the eternal Absolute. ${ }^{63}$

The last verse, which is repeated in several later medical works, ${ }^{64}$ seems to promise a kind of immortality, depending on how we interpret brahma tathaiti cākșayam, here rendered as "attains the eternal Absolute." Cakrapānidatta's eleventh-century commentary on Carakasaṃhitā Cikitsāsthāna 1.1.78-80 glosses brahma with mokșa, i.e., liberation from the cycle of rebirths. ${ }^{65}$ This suggests immortality outside an embodied existence.

But what about embodied immortality? Many medical works allow for longevity beyond the paradigmatic one hundred years as an outcome of rasāyana therapy, ${ }^{66}$ and some formulations are described as increasing lifespan accord-

63 yathāmarāṇām amṛtam yathā bhogavatām sudhā / tathābhavan maharșin̄ạm rasāyanavidhih purā // 78 na jarām na ca daurbalyạ̣ nāturyạ̣ nidhanam na ca /

jagmur varșasahasrāṇi rasāyanaparāh purā // 79 na kevalạ̣ dīrgham ihāyur aśnute rasāyanam yo vidhivan niṣevate | gatị̣ sa devarșinișevitām śubhām prapadyate brahma tathaiti cākșayam // 80

64 See Siddhayoga 69.72, Vañgasenasaṃhitā rasāyanādhikāra 510, Yogaratnākara 76.37, and Bhāvaprakāśa Uttarakhaṇda 2.15 .

65 For the text of Cakrapānidatta's commentary of the Carakasamnitā, see the edition of the Carakasaṃhitā by Trikamji Āchārya.

66 For example, in the Aștāingahṛdayasaṃhitā, one recipe is for 200 years of life, two recipes 
ing to how long they are taken. For example, the Suśrutasaṃhitā claims that each month of intake of a false black pepper (vidanga) compound increases lifespan by a hundred years. ${ }^{67}$ The same concept is found in the Carakasamhit $\bar{a}$ (Cikitsāsthāna 1.2.13) where the number of emblic myrobalan fruits eaten equals the number of years added to one's life. Theoretically, that should mean that lifespan could be extended indefinitely through a continuous intake of rasāyanas.

Still, it should be noted that promises of bodily immortality are unusual and occur only in a few instances, though we find the idea of keeping death at bay or preventing an untimely death a number of times. Sometimes, it is not entirely clear whether formulations are meant to bring about a rescue from death at a particular time, or whether the effect is meant to be permanent. The Aștāngasamgraha gives a recipe for an iron preparation through which the consumer would "overcome all troubles and become unassailable by disease, ageing, death, weapons, fire, water, and poison." 68 And some four hundred years later, the Vangasenasamnhitā, which shows influence from alchemical literature in a number of its rasāyana formulations, describes a multi-herb compound as providing the consumer with a body that is free from ageing, disease and death (jarārujämrtyuvimuktadeha). ${ }^{69} \mathrm{~A}$ further recipe for a compound containing iron and guggul uses the phrase yāti amaratvam - "he reaches immortality"which seems fairly unambiguous. ${ }^{70}$ Note, however, Olivelle on Thieme's 1968 study of the related term $a m r t a$ and the verbal root $m r$ in Vedic literature: "The term amrta does not always mean immortal in the sense we usually attach to it; it often means vitality or vital energy (Thieme's Lebenskraft) — it is a full and prosperous life and all things that sustain and promote such a life, including food, drink, cattle, and medicine. Amrta can thus indicate both life/immortal-

for 300 years, one recipe for 1000 years, one recipe for 500 years, and one recipe for a double life span. In the Siddhayoga, we find recipes promising 500 and 1000 years of life.

67 See the recipe in Suśrutasaṃhitā Cikitsāsthāna 27.7.

68 tatah sarvopatāpān jitvā vyādhijarāmaranaśastrāgnitoyavișānām agamyah (...)//53// The full recipe is found in Aștāingasamgraha Uttarasthāna 49. 53-54.

69 Vañgasenasaṃhitā rasāyanädhikāra 396. The same recipe is found in Yogaratnākara 76.13-14 and in Bhāvaprakāśa Uttarakhaṇ̣̂a 2.11-12. See also Vañgasenasaṃhitā rasāyanādhikāra 116, where a mixture of sulphur, the three myrobalans and false daisy (bhringarāja) is attributed with removing death and ageing (mrtyujarāpaha); or rasāyanādhikāra 119, which describes a sulphur and iron preparation as letting someone live to the end of the moon and sun (jīved ācandratārakam).

70 See variants of the recipe in Vangasenasaṃitā rasāyanādhikara ${ }_{423}$, Yogaratnākara 76.27 and Bhāvaprakāśa Uttarakhanḍ 2.14 . 
ity, as well as instruments that sustain life and ward off death."71 Perhaps we can apply similar meanings to the related terms mrtyu and amara. Correspondingly, the "body that is free from death" (... mrtyuvimuktadeha), in the example above, then might be understood as a body full of vitality, rather than one that is free from death forever, while to attain amaratvam might be understood in terms of a gain in vitality instead of immortality.

In the early medical works up to the Varigasenasamnitā, bodily immortality is typically not presented as an outcome of medical intervention. The author of the thirteenth/fourteenth-century medical treatise Śärngadharasaṃhitā (1.5 .5ocd-52ab) states this explicitly:

The conjunction of body and breath is called life.

Their separation through time is called death by the wise.

No living being born anywhere on earth is immortal.

Hence, death is inevitable. However, one should ward off disease. ${ }^{72}$

Importantly, the author gives a reason why health should be pursued:

Given that the body is an instrument for accomplishing righteousness, wealth, pleasure, and liberation, a man who understands the consequences of past actions should protect the body from diseases. ${ }^{73}$

Thus, the body is used for the pursuit of this-worldly aims but is also a crucial means for the attainment of religious merit and the final goal of liberation from the cycle of rebirths. ${ }^{74}$

71 Patrick Olivelle, "Amṛtā: Women and Indian Technologies of Immortality." Journal of Indian Philosophy 25 (1997): 428.

72 śarīraprāṇāyor eva saṃyogād āyur ucyate // 5ocd kālena tadviyogāc ca pañcatvam kathyate budhaih $\mid$ na jantụ̣ kaścid amarah prthryām jāyate kvacit // $5^{1}$ ato mrtyur avāryah syāt kiṃtu rogān nivārayet /

73 dharmārthakāmamokșaṇām șarīraṃ sādhanaṃ yataḥ / ato rugbhyas tanum rakṣen naraḥ karmavipākavid //53//

74 See also Carakasaṃhitā Sūtrasthāna 1. 6, where disease is described as an impediment to religious observances, such as austerities (tapas), abstinence (upavāsa), study (adhyaya$n a$ ), celibacy (brahmacarya), and vows (vrata), as well as to lifespan. See also Carakasamhitā Sūtrasthāna 1.15, which states that freedom from disease is the root cause of righteousness, wealth, pleasure, and liberation-dharmārthakāmamokșānạ̄̄ ārogyam mūlam uttaman. Notably, none of the rasāyanas or other medicines in the Śạrngadharasmhitā are described as especially extending lifespan, so that the suggestion seems to be that the attainment of liberation (mokșa) is possible within a regular lifespan. 
Special powers as effects of rasāyana medicines are found throughout the medical treatises. They are an integral, though minor part of rasāyana.

Many of the special effects of rasāyana medicines concern averting misfortune and malevolent acts. Rasāyanas here function as shields against attacks, rendering them ineffectual. Notably, the possibility of (counter-)attacks is missing: the purpose of rasāyanas is defensive, not offensive. The other function of these rasāyanas is to bring about positive effects, often directed at improving social standing, such as fame, wealth, and success in one's endeavors. Here, rasāyanas may not only affect the consumers, but also their social environment: the powers bestowed on the consumers determine society's reaction to them. The first function of these rasayyanas points to an essentially hostile environment in which all sorts of calamities may befall a person, many of them caused by the malign actions of others. The second seems to reflect an optimism about the possibility to nevertheless live a happy life in favorable conditions. These effects of rasāyana medicines are reminiscent of some of the effects attributed to mantras and rituals of the Atharvaveda and its ancillary texts. The difference is that many of the Atharvaveda's spells are dedicated to damaging one's enemy - these kinds of spells are alluded to in the Asțāngahrdayasamnhitā and Asțāngasamgraha, as we have seen, but only as something the rasāyana will guard against, not as something a rasāyana would effect. It should also be mentioned that while mantras are sometimes cited in rasāyana chapters, typically to accompany a rasāyana's intake, they are not specifically associated with special powers for good luck or protection from malign forces. ${ }^{75}$

75 The exceptions to this are Suśrutasaṃhitā Cikitsāsthāna 28.25, which states that the Gāyatrī mantra should be spoken during the making of the formulations that confer such special powers; and Cikitsāsthāna 30.27, which prescribes the incantation of a mantra during the harvest of divine herbs (divyaușadhi). Otherwise, mantras occur in Suśrutasaṃhitā Cikitsāsthāna 28.25, Aștāñgahṛdayasaṃhitā Uttarasthāna 39.89, and Aștāñgasaṃgraha Uttarasthāna 49.83 in the context of chaulmoogra oil (tuvaraka), an oil used against skin diseases (kuștha); in Aștāngasamgraha Uttarasthāna 49. 262-263 in the context of taking guggul against diseases caused by the humors wind and phlegm; in the Siddhayoga 69.31 for the intake of flame of the forest (hastikarna) and 69.41 for taking marking nut (bhallätaka) for general good health and enhancing cognitive power; in the Cakradatta 66.100-106 in the context of taking the iron tonic called amrtasāralauha for a beautiful, stable, and healthy body, and in 66.19-21 for the intake of flame of the forest (hastikarna) for longevity; in the Vangasenasamhitä's rasāyana chapter, verse 120, for the use of a sulphur and iron compound which would confer divine sight and longevity on the consumer. Mantras are not found in the rasāyana chapters of the Carakasaṃhitā, the Bhāvaprakāśa, or the Yogaratnākara. 
The other kind of effects of rasāyanas are more easily integrated into a medical framework of physical health as an extension of normal human corporeality and functioning. Here, bad eyesight becomes good vision and then divine vision; a breaking voice becomes smooth and powerful, turning into an instrument for eloquence and oration skills, which in turn culminate in "mastery of speech" ( $v \bar{a} k s i d d h i)$; an untimely death is averted and replaced by the appropriate life-span of a healthy human being, or extended to an extraordinary length, or expanded indefinitely. The ultimate promise of rasāyana is the perfection of the body that will allow a sustained pursuit of both worldly pleasures and transcendent goals.

It is tempting for a modern reader to explain the inclusion of special powers as an effect of rasāyana as hyperbole: exaggerations perhaps used to claim an elevated position for rasāyana within medicine. Accordingly, 1000 years of lifespan would just mean "a long life;" divine sight $20 / 20$ vision; an adamantine body good immunity; and the cure of leprosy and regeneration of lost limbs an alleviation of symptoms. This is certainly how modern proponents of Ayurveda tend to frame the workings of rasäyana medicines. That is, special powers or extreme effects are simply left unmentioned, played down or dismissed. We can see this mindset at work in translations, but also in the careful wording and emphasis on health benefits in research papers and other publications on rasāyana formulations. ${ }^{76}$ This is not surprising, given that modern practitioners of Âyurveda have long been trained to work within the modern biomedical idiom.

Examining the texts as historical sources, however, we can note that the special powers, while not especially given prominence, form part and parcel of the medical writers' representations of rasāyana. Summarizing research findings on yogic powers in different Indic literatures, Jacobsen notes that " $(t) h e$ traditions assumed that the powers could be explained rationally, neither considered unreal, nor denied as irrational." ${ }^{\prime 7}$ This is also the impression I gain from the medical texts, though there is a certain ambiguity in some expressions

$7^{6}$ An online search for the term rasāyana brings up many research publications on specific rasāyana formulations or single drugs. These are all focused on their health benefits and do not mention special powers as possible outcomes of rasāyana therapy. See also the representations of rasāyana in Chittabrata Palit and Nupur Dasgupta, Ancient Indian System of Rasayana Suvarnatantra. A Treatise on Alchemy/Rasayana (Delhi: Kalpaz Publications, 2009), S. Mahdihassan, Indian Alchemy or Rasayana in The Light of Ascetiscism and Geriatrics (Delhi: Motilal Banarsidass, 1991), Ram Karan Sharma, Rejuvenative Health Care in Ayurveda (Delhi: Pratibha Prakashan, 1996), and Ajay Kumar Sharma, Elements of rasāyana Therapy in Ayurveda (Delhi: Sri Satguru Books, 2005). 
that allow for either a more mundane or a supramundane interpretation. The boundaries between normal and extraordinary are fluid and are not marked in the texts: the cure of cough can be juxtaposed with the extension of life for eight hundred years. Where do we draw the line? Do we accept claims of efficacy in Âyurvedic medicines? And if so, what is the limit to this acceptance? How do we distinguish between reasonable and unreasonable claims, between normal and extraordinary? The medical writers do set certain limits, as we have seen, for example, in the descriptions of normal lifespan. These limits are then, however, stretched in the rasāyana chapters. This may reflect the juxtaposition of materials collected from different sources. After all, the medical works are collections, and the doctrine of rasāyana may have been based on a different set of rules than other branches of medicine.

In his pioneering book, Asceticism and Healing in Ancient India, Kenneth Zysk argued that the early medical works display "empirico-rational" and "magico-religious" elements that reflect the different cultural milieus in which medicine was developed. According to Zysk, the empirical and rational theories of medicine (especially humoral theory) originated in ascetic milieus, while the magico-religious elements were part of a "brahmanic veneer" applied while adapting medical theory and practice to brahmanic culture. The division between "empirico-rational" (as indicative of modern ideas of science) and "magico-religious" was critiqued by Engler on the grounds that "Ayurveda did not manifest standard criteria of "science" (e.g., materialism, empirical observation, experimentation, falsification, quantification, or a developed conception of proof) and that Vedic aspects of the classical texts are too central to be considered inauthentic or marginal. ${ }^{78}$ More recently, Slouber (2016) has shown how certain religious and magical elements found in the texts follow a systematic logic and should therefore not be categorized as irrational. Nevertheless, the difference in approaches in the medical texts is fairly clear and indeed is explicitly referenced in the source texts themselves. For example, the Carakasamhita divides therapy into three categories: 1 . that which depends on the sacred (daivaryapāśraya); 2. that which depends on reasoning (yuktivyapāśraya); and 3. that which triumphs through good character (sattvāvajaya). The first category includes "the use of mantras, herbs, jewels, good-luck ceremonies, food offerings to the gods, presents to the gods, fire oblations, pledges, penances, fasts, benedictions, prostrations, and pilgrimage." ${ }^{79} \mathrm{The} \mathrm{sec-}$

78 Steven Engler, “'Science' vs. 'Religion' in Classical Ayurveda," Numen 5o (2003): 416.

79 Carakasaṃhitā Sūtrasthāna 11.54. Translation by Dominik Wujastyk, Roots, 33. 
ond employs diet and medicines. For the third, the mind is turned away from detrimental thought. ${ }^{80}$ Rasāyana encompasses all three approaches.

I have avoided the use of the words "supernatural" or "magical" to describe the effects of rasāyana medicines, since the way in which medical writers incorporate special powers points to their seeing them as part of how the world functions, not as a disruption of any natural laws. Even the words "special" or "extraordinary" must be used with some caution, since they depend on a specific understanding of what is normal, or common. In his study on yoga powers in Śava tantric traditions, Somadeva Vasudeva suggests the use of "supramundane abilities" for the word siddhi to reflect the idea that these abilities are not common for ordinary humans, though they are for accomplished yogins. ${ }^{81}$ Perhaps we can similarly understand the special effects of rasāyana as something that is not commonly available to all, but can be attained under special circumstances by certain kinds of persons, letting them achieve the "normal" state of higher beings, such as seers, sages, and gods. In the world view of the medical authors, these effects of rasāyanas are then only special or extraordinary in that they require special or extraordinary effort.

\section{Acknowledgements}

This article was made possible through funding from the European Union's Horizon 2020 research and innovation program under grant agreement No. 639363 .

\section{References}

\section{Primary Sources}

[Aștānigahrdayasaṃhitā:] Vāgbhața's Așțānga Hṛdayam: Text, English Translation, Notes, Appendix and Indices, translated by K.R. Srikantha Murthy. 3 vols. Fourth edition. Varanasi: Krishnadas Academy, 1999-200o.

80 The Suśrutasaṃhitā offers a tripartite classification of diseases in Sūtrasthāna 24.4. One of these is the category of "ādhidaivika", explained in 24.7 as caused by offending gods, curses, black magic (atharvana) and misfortune. However, the passage offers no corresponding therapeutic approach here.

81 Somadeva Vasudeva, "Powers and Identities: Yoga Powers and the Tantric Śaiva Traditions," in Yoga Powers: Extraordinary Capacities Attained Through Meditation and Concentration, ed. Knut Jacobsen (Leiden: Brill, 2011), 265. 
[Aștāñgasamgraha:] Aștāinga Saṃgraha of Vāgbhața: Text, English Translation, Notes, Indices etc., translated by K.R. Srikantha Murthy. 3 vols. Varanasi: Chaukhamba Orientalia, 1995-1997.

Bhaișajyaratnāvalī of Shri Govinda Dasji, edited and enlarged by Brahmashankar Mishra, commented upon by Ambikadatta Shāstrī, English translation by Kanjiv Lochan, translation technically reviewed by Anand K. Choudhary. 3 vols. Varanasi: Chaukhambha Sanskrit Bhawan, 2006.

Bhāvaprakāśa of Bhāvamiśra: Text, English Translation, Notes, Appendeces[sic] and Index, translated by K.R. Srikantha Murthy. 2 vols. Varanasi: Krishnadas Academy, 1998-2000.

[Bower Manuscript:] Nāvanitakam or (The Bower Manuscript): Critically Edited with Various Readings and Restorations for the First Time from the Editio Princeps of the Late D. Hoernle by Kavirāj Balwant Singh Mohan, Vaidya-Vacaspati. Lahore: Mehar Chand Lachman Das, 1925 .

Carakasaṃhitā: Agniveśa's Treatise Refined and Annotated by Caraka and Redacted by Drdhabala, Text with English Translation, edited and translated by Priyavat Sharma. 4 vols. Eighth edition. Varanasi: Chaukhamba Orientalia, 2003.

[Carakasaṃhitā:] The Charakasaṃhitā of Agniveśa:Revised by Charaka and Dridhabala, with the Āyurveda-Dīpikā Commentary of Chakrapānidatta, edited by Vaidya Jādavaji Trikamji Āchārya. Fifth edition. Delhi: Munshiram Manoharlal, 1992.

Cakradatta, Text with English Translation: A Treatise on Principles and Practices of Ayurvedic Medicine. Varanasi, Delhi: Chaukhamba Orientalia, 1994.

Vañgasena Saṃhitā or Cikitsāsāra Saṃgraha of Vañgasena: Text with English Translation, Notes, Historical Introduction, Comments, Index and Appendices by Nirmal Saxena. 2 vols. Varanasi: Chowkhamba Sanskrit Series Office, 2004.

[Rasaratnākara Rasendrakhaṇda:] Śrīh siddhanityanāthapran̄itah rasaratnākaraḥ / (samastarasagranthānām śirobhūṣaṇam). Māthuravaiśyā 'yurvedoddhāraka śālagrāmakṛta bhāṣāțīkāvibhūṣitah / sa ca Kșemarāja Śrīkrș̣nādāsaśraṃșthinā. Mumbai: Śrīvenkațeśvara Steam Press, 1966.

[Rasaratnākara Rasāyanakhạ̣da:] Rasāyanakhanda: Fourth Part of Rasaratnākara of Śrī Nitya Nātha Siddha, edited by Vaidya Jādavjī Tricumjī Āchārya. Benares: Vidya Vilas Press, 1939.

Rasārnava, accessed at Oliver Hellwig's online Digital Corpus of Sanskrit (DCs) at http://www.sanskrit-linguistics.org/dcs/.

[Śārngadharasaṃhitā:] Śārngadhar-Saṃhitā (A Treatise on Āyurveda) by Śārngadhara, translated by Āyurveda-Vidwān Prof. K.R. Srikantha Murthy. Jaikrishnadas Ayurveda Series 58. Varanasi, Delhi: Chaukhamba Orientalia, 1984.

[Siddhayoga:] The First Treatise of Āyurveda on Treatment: Vrndamādhava or Siddha Yoga, edited and translated by Premvati Tewari and Asha Kumari. 2 vols. Varanasi: Chaukhambha Visvabharati. 
[Suśrutasaṃhitāa] Suśruta-saṃhitā with English Translation of Text and Dalhaṇa's Commentary Along with Critical Notes, edited and translated by Priya Vrat Sharma. 3 vols. Varanasi: Chaukhambha Visvabharati, 1999-2001.

[Yogaratnākara:] A Complete Treatise of Āyurveda: Yogaratnākara, edited and translated by Asha Kumari and Premvati Tewari. 2 vols. Varanasi: Chaukhambha Visvabharati, 2010.

\section{Secondary Sources}

Barois, Christèle. "Stretching Out Life, Maintaining the Body: Part I-Vayas in Medical Literature." History of Science in South Asia Special Issue "Rejuvenation, Longevity, Immortality in South Asian Medical, Alchemical and Yoga Traditions" 5, no. 2 (2017): 37-65. https://doi.org/10.18732/hssa.v5i2.31.

Dasgupta, Nupur. "Rasa, Rasayana, Rasatantra: Exploring Concepts and Practices." In Ancient Indian System of Rasayana Suvarnatantra: A Treatise on Alchemy/Rasayana, edited by Chittabrata Palit and Nupur Dasgupta, 9-61. Delhi: Kalpaz Publications, 2009.

Engler, Steven. “'Science’ vs. 'Religion' in Classical Ayurveda." Numen 50 (2003): 416463.

Falk, Harry. "Soma I and II." Bulletin of the School of Oriental and African Studies 52 (1989): 77-9o.

Filliozat, Jean. The Classical Doctrine of Indian Medicine: Its Origins and its Greek Parallels. First English edition, translated by D.R. Chanana. Delhi: Munshiram Manoharlal, 1964 .

Fenner, Edward Todd. Rasayana Siddhi: Medicine and Alchemy in the Buddhist Tantras. Ph.D. thesis, University of Wisconsin-Madison, 1979.

Goudriaan, Teun. Māyā Divine and Human. Delhi, Varanasi, Patna: Motilal Banarsidass, 1978.

Hellwig, Oliver. "Rasāyana und die āyurvedische Krankheitskunde." Traditional South Asian Medicine 8 (2008): 32-64.

Jacobsen, Knut A. Yoga Powers: Extraordinary Capacities Attained Through Meditation and Concentration. Leiden: Brill, 2011.

Maas, Philipp A. "On What Became of the Carakasaṃhitā After Dṛ̣habala’s Revision.” eJournal of Indian Medicine 3, no. 1 (2010): 1-22.

Maas, Philipp A. "On the Meaning of rasāyana in Classical Yoga and Āyurveda." History of Science in South Asia Special Issue "Rejuvenation, Longevity, Immortality in South Asian Medical, Alchemical and Yoga Traditions" 5, no. 2 (2017): 66-84. https://doi.org/ 10.18732/hssa.v5i2.32.

Mahdihassan, S. Indian Alchemy or Rasayana in The Light of Ascetiscism and Geriatrics. Delhi: Motilal Banarsidass, 1991.

Mallinson, James and Mark Singleton. Roots of Yoga. London: Penguin Random House U K, 2017. 
Meulenbeld, J.G. A History of Indian Medical Literature. 5 vols. Groningen: Egbert Forsten, 1999-2002.

Meulenbeld, J.G. "The Woes of ojas in the Modern World." In Modern and Global Ayurveda: Pluralism and Paradigms, edited by Dagmar Wujastyk and Frederick M. Smith, 157-175. Albany: SUnY Press, 2008.

Olivelle, Patrick. "Amṛtā. Women and Indian Technologies of Immortality." Journal of Indian Philosophy 25 (1997): 427-449.

Palit, Chittabrata and Nupur Dasgupta, eds. Ancient Indian System of Rasayana Suvarnatantra. A Treatise on Alchemy/Rasayana. Delhi: Kalpaz Publications, 2009.

Pensa, Corrado. "On the Purification Concept in Indian Tradition, with Special Regard to Yoga." East and West 19, nos. 1-2 (1969): 194-228.

Pflueger, Lloyd W. "Holding On and Letting Go: The In and Out of Power in Classical Yoga." In Yoga Powers: Extraordinary Capacities Attained Through Meditation and Concentration, edited by Knut A. Jacobsen, 241-264. Leiden: Brill, 2011.

Radich, Michael. "Immortal Buddhas and Their Indestructible Embodiments." Journal of the International Association of Buddhist Studies 34, nos. 1-2 (2011 (2012)): 227290.

Roşu, Arion. "Considerations sur une technique du rasāyana āyurvedique." Indo-Iranian Journal 17 (1975): 1-29 and 395.

Sharma, Ajay Kumar. Elements of rasāyana Therapy in Ayurveda. Delhi: Sri Satguru Books, 2005.

Sharma, P.V. Āyurveda kā vaijñannika itihāsa. Vārānāsi: Caukhambā Oriyanțāliyā, 1975.

Sharma, Ram Karan. Rejuvenative Health Care in Āyurveda. Delhi: Pratibha Prakashan, 1996.

Slouber, Michael. Early Tantric Medicine: Snakebite, Mantras, and Healing in the Garuda Tantras. Oxford: Oxford University Press, 2016.

Vasudeva, Somadeva. "Powers and Identities: Yoga Powers and the Tantric Śaiva Traditions." In Yoga Powers: Extraordinary Capacities Attained Through Meditation and Concentration, edited by Knut A. Jacobsen, 265-302. Leiden: Brill, 2011.

Thieme, Paul. "Ambrosia." In Indogermanische Dichtersprache, edited by Rüdiger Schmitt. Darmstadt: Wissenschaftliche Buchgesellschaft, 1968.

Wujastyk, Dagmar. “Acts of Improvement." History of Science in South Asia Special Issue "Rejuvenation, Longevity, Immortality in South Asian Medical, Alchemical and Yoga Traditions" 5, no. 2 (2017): 1-36. https://doi.org/10.18732/hssa.v5i2.26.

Wujastyk, Dagmar. "On Perfecting the Body: rasāyana in Sanskrit Medical Literature." AION-sezione filologico-letteraria 37 (2015): 55-8o.

Wujastyk, Dominik. "The Path to Liberation through Yogic Mindfulness in Early Ayurveda." In Yoga in Practice, edited by David Gordon White, 31-42. Princeton: Princeton University Press, 2011.

Wujastyk, Dominik. The Roots of Ayurveda. London: Penguin Books, 2003. 
Zysk, Kenneth G. "Potency Therapy in Classical Indian Medicine." Asian Medicine 1, no. 1 (2005): 101-118.

Zysk, Kenneth G. Asceticism and Healing in Ancient India: Medicine in the Buddhist Monastery. Delhi: Motilal Banarsidass, 2000 [1991]. 